\title{
Impact of Consumption and Investment onto Growth: An Example of the Republic of Srpska
}

\author{
Boris Spasojević ${ }^{1}, \&$ Aleksandar Đukić ${ }^{2}$ \\ ${ }^{1}$ Mag. Boris Spasojević, Mag.Econ, Catering, Trade and Tourism Vocational School, Banja Luka, Bosnia and \\ Herzegovina \\ ${ }^{2}$ Aleksandar Đukić, B.Sc.Hon.Econ., Catering, Trade and Tourism Vocational School, Banja Luka, Bosnia and \\ Herzegovina \\ Correspondence: Aleksandar Đukić, B.Sc.Hon.Econ., Catering, Trade and Tourism Vocational School, Banja Luka, \\ Bosnia and Herzegovina.
}

Received: July 23, 2018 Accepted: August 31, $2018 \quad$ Available online: September 17, 2018

doi:10.11114/aef.v5i6.3632 URL: https://doi.org/10.11114/aef.v5i6.3632

\begin{abstract}
The economy of the Republic of Srpska is burdened by inherited (structural) issues and a sluggish adjustment of the current economic policy to the contemporary global trends. According to the standards of the WB, IMF and Kuznets, the Republic of Srpska is classified as a small economy. Just like Bosnia and Herzegovina or any other countries of Western Balkans, it too is finalising the transition to a market economy. The Republic of Srpska features insufficient GDP growth rates. Under such circumstances, there is a need for enticement of GDP growth. Consumption (both final and public) as well as all forms of investment affect economic growth, with FDIs having a particularly important role. In most countries, there is a positive correlation between investment and GDP growth. Likewise, there is a positive correlation between GDP growth and final consumption. Therefore, the Republic of Srpska, as well as any other small economy, resorts to attracting investments and increasing final consumption. However, the issue is that public debt maintains its growing trend in most of such transitional economies. This paper contains the quantification of the impact of investments and consumption onto the GDP of the Republic of Srpska. It has been proven that the final consumption and investments affect GDP growth in the Republic of Srpska. Correlation-regression analysis confirmed a positive correlation between the mentioned variables. This development policy affects the continuous growth of public debt and brings the increase in the share of government (public) consumption in total consumption. In addition, it also affects the insufficient efficiency of investments. As a consequence, low productivity and insufficient competitiveness emerge, followed by the occurrence of other economic and social problems. Therefore, the Republic of Srpska and Bosnia and Herzegovina need to complete the initiated reforms and expedite their EU integration, modernize and restructure their industry as per the requirements of the global market, reduce the costs of public institutions and increase their overall competitiveness.
\end{abstract}

Keywords: final consumption, investments, growth, GDP, Republic of Srpska, small economy

\section{Introduction}

The Republic of Srpska (hereinafter referred to as „RS“), constitutes the state of Bosnia and Herzegovina (BiH) as one of its two entities. This complex and very much specific country was established by the Dayton Agreement (1995). It serves as a de facto constitution of this multiform and socially multi-layered community. It regulates all aspects of state regulation, as well as economic issues. Competencies from the field of economics are split onto the entity level or on a joint (state) level. Likewise, it is important to note that Bosnia and Herzegovina nowadays operates as a customs and monetary union. Foreign trade legislation as well as a common monetary policy with a single central bank are the key levers of organization of the economic sector in $\mathrm{BiH}$ and its entities. However, there are differences in the field of taxation, since, for example, indirect taxation is under the jurisdiction of the state of Bosnia and Herzegovina, whereas the collection and control of direct taxes is under the jurisdiction of its entities. As for the investments, the investment policy is based on market principles, whereas some activities and public investment are largely left to be governed by the entities. In addition to the budget of the state of $\mathrm{BiH}$, each of its entities has its own budget. Therefore, most of the public investments and public spending comes from the entities' budgets, but also from the budget of $\mathrm{BiH}$ as well. 
Therefore, at this stage of development, budget spending and investments are the most important growth generators of $\mathrm{BiH}$ and RS. Moreover, the Republic of Srpska, just like BiH and most of the Western Balkan countries, is in the course of finalizing the transition from the socialist method of organization, operation and thinking towards a market-oriented economy and democratization.

The influence of various factors on growth and development represents a professional challenge for many researchers. In an effort to do so, the researches and experiences from small countries, particularly transitional and post-transitional countries are particularly useful. The reason is that they are mainly struggling with current economic difficulties, in addition to inherited (structural and other) problems. However, with proper development these countries are able to achieve higher growth rates than developed countries that have apparently slowed down their growth by 2-3 times over the past 50 years (Juknys, Liobikiene, Dagiliute, 2018).

This type of research features a distinct economic definition of small countries. According to WB and IMF standards, small countries are those countries that have the population of less than 1.5 million. The indicator of a small country for Simon Kuznets is the population of less than 10 million inhabitants (Kuznets, 1960), and according to this definition, most countries of the Western Balkans are classified as small countries. Thus, according to the WB and the IMF, Bosnia and Herzegovina is not a small country, while on the other hand, the Republic of Srpska, as its entity - is.

The development of all countries, particularly the small ones, depends on a number of factors. The liberalization of the trends in investment and trade, that is, of goods and investments, is clearly dominant (Krugman \& Obstfeld, 2009). Numerous researches show that FDI have a positive impact on growth, whereas labour, openness of trade and economic freedom are the key determinants of foreign direct investment, which in turn encourages further growth (Iamsiraroj, 2016).

Small countries are also bothered by a substantial development gap compared to the world's leading economies and the fact that capitalism has entered its mature phase (Wai Li, 2017). In that sense, once it joins the EU, the Republic of Srpska shall be met with major issues in the area of competitiveness. Real growth rates in developing countries should be much higher than in developed countries, in order to enable them to eventually catch up with the standard of developed countries (Alimi, 2016). Nowadays, the Republic of Srpska features limitations in achieving higher growth rates (which should be 5-6\% by most authors). Such expected and desired growth rates were successfully met prior the crisis (which occurred in years of 2008/2009). However, the crisis has slowed down the growth in the long run, with the negative effects still being felt. The Republic of Srpska and the countries of the Western Balkans aim to achieve faster growth.

Consumption (both final and public) stimulates growth, along with all respective forms of investment. Therefore, FDIs play a particularly important role, mainly for small and post-transition countries. All related analyses indicate that investments of all forms (foreign, domestic, private or public) positively influence GDP growth. This issue is addressed by many researchers. Even the conservatism of a country is negatively linked to investments (Ha, Feng, 2018). Furthermore, research has shown that the impact of GDP growth and foreign direct investment on economic freedom is fairly consistent between the countries of Eastern Europe and the Western Balkans (Sayari, Sari, Hammoudeh, 2018). Speaking of public consumption, empirical research based on a set of 80 countries in the period 1970-2010 shows that when governments act responsibly in terms of public spending, their countries consequentially achieve economic growth (Morozumi, Veiga, 2016). Therefore, European experiences are important for the Republic of Srpska, because ever since the 1980s the governments of the EU have set the goal of rationalizing public spending (Alonso, Clifton, Diaz, 2017).

Small countries are often forced to implement long-term unfavourable development policies and methods. Due to low aggregate demand and insufficient production, they are resorting to the growth of public spending at the expense of the increase in public debt. For countries in transition, the growth trend of public debt is inevitable (Chatterjee, Gibson, Rioja, 2017). In addition, international debt affects small countries with relatively high income in a significantly different way than it affects small, low-income countries (Kaminarides, Nissan, 1993). The research conducted by Williams and Baek identifies the possibility of universal mechanisms that lead to general laws governing the trend of economic and GDP growth (Williams, Baek, 2017), but this analysis is limited to the quantification of the impact of investment and consumption onto output.

The subject paper is focused on the impact of consumption and investment onto growth.

Makiela and Ouattara claim that investments have a greater impact on economic growth in developing countries than in highly developed countries (Makiela, Ouattara, 2018). Likewise, Borgonovo and Peccati made a value-for-investment model that differs for each country, identifying sectors with the highest investment efficiency (Borgonovo, Peccati, 2006). Ventelou and Bry assessed the impact of spending onto economic growth. They defined the role of spending in the process of economic growth (Ventelou, Bry, 2006). Shen and Yang focused their research on open low-income 
countries where sustainable economic growth depends on the continuity of consumption and investment (Shen, Yang, 2018).

\section{Research Methodology}

In addition to comparative and descriptive analysis, detailed correlation and regression analysis are also used.

The linear regression model represents the regression equation: $Y i=\beta_{0}+\beta_{1 * x i}+\varepsilon_{\mathrm{i}} \quad(i=1, \ldots, n)$

where the index $i$ refers to $i$-th observation, whereas the variable $x$ is an independent explanatory variable, since it explains the variations of the variable $y$.

Estimated function of free linear regression is based on the sample: $\hat{Y} i=b_{0}+b_{1} x i$

with $\hat{Y} i$ being the value of dependant variable located on the best adjusted regression line, whereas $b_{0}$ and $b_{1}$ are the estimates of the unknown regression parameters of the basic set.

Regression and correlation analysis, alongside with other analyses of GDP and its constituent components (consumption and investment) provide a response to the hypothesis that consumption and investments are fuelling economic growth. The analysis involves reading the following indicators: mean, median, max (maximum), min (minimum), std. dev. (standard deviation), probability (p), skewness, kurtosis, std. error (standard error estimation), coefficient of correlation, t-statistics and f-statistics. Furthermore, Durbin-Watson (D.W.) statistics measures the serial correlation between the residuals. Test D.W. reports on test statistics, with values ranging from 0 to 4 . F-statistics is used for simultaneous check of the relevance of all variables in the model. Once the f-statistics test is used, it can be said whether the model is statistically relevant. If this value is greater than the value given in the table, a test for the validity of the econometric model is used. Likewise, it is assumed that the model is appropriate if the probability of prob (f-statistic) is less than 0.05 . The zero hypothesis is rejected in case none of the variables in the model is statistically relevant. In addition to statistical analyses, the comparative and descriptive method will be used for the relevance of research and proving the hypothesis.

\section{Assessment of Impact of Final Consumption and Investment onto GDP Growth}

\subsection{GDP Growth Analysis}

Growth rates in the Republic of Srpska, the Federation of BiH and BiH are roughly equal for the period 2006-2016. In the Republic of Srpska, the real GDP growth rates are the same based on all three approaches to GDP calculation, which is theoretically true, whereas the real growth rates of GDP in Bosnia and Herzegovina are not harmonized with the consumption rates on the basis of production and income approach. The following graph shows the GDP movement.

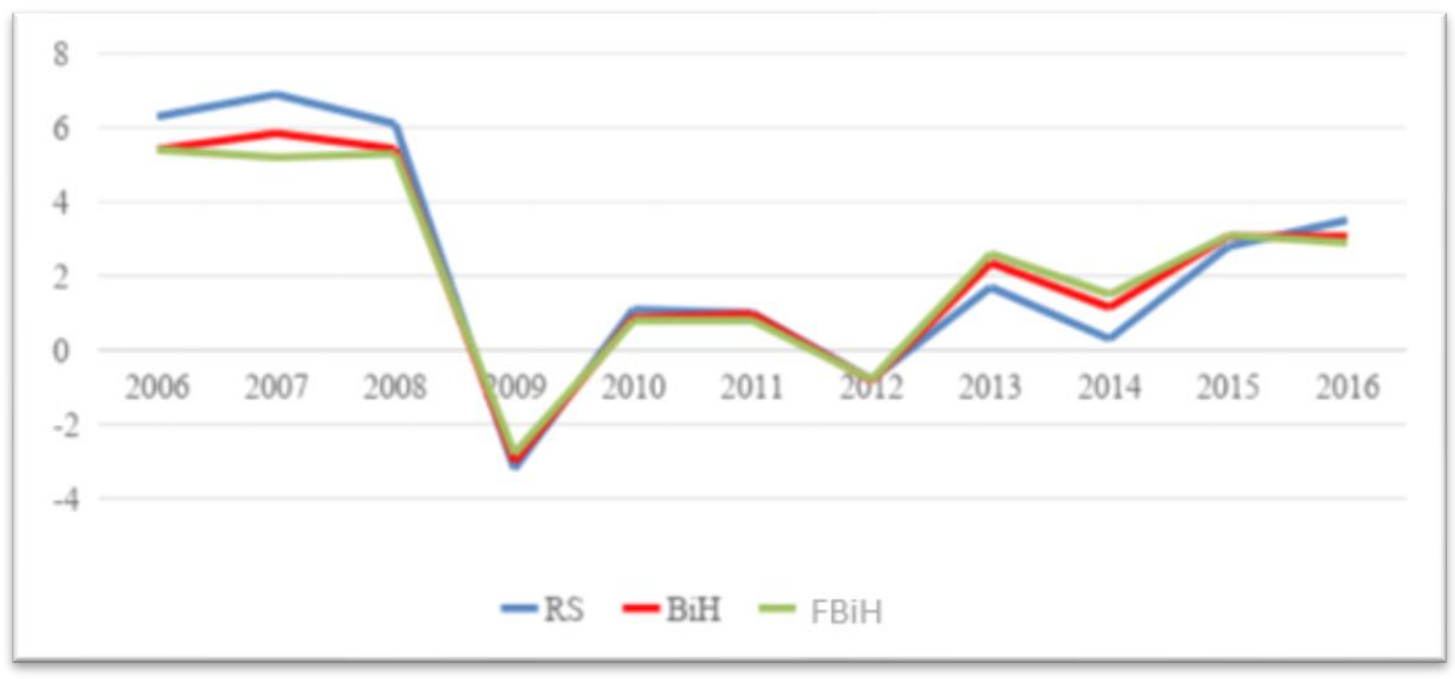

Figure 1. GDP rates in the Republic of Srpska, Federation of BiH and Bosnia and Herzegovina

Source: Institute of Statistics of the Republic of Srpska, Federal Statistics Office and Agency for Statistics of Bosnia and Herzegovina

The period from year 2006 to 2016 saw high growth rates until the crisis in 2009, with the average growth rate amounting to $6.3 \%$. In 2009, economic activities were significantly reduced as a result of the crisis. The EU also registered a $4.4 \%$ decline, as well as the most important foreign trade partners of Bosnia and Herzegovina such as Germany $(-5.6 \%)$, Croatia $(-7.4 \%)$, Italy $(-5.5 \%)$, Austria $(-3,8 \%)$, Slovenia $(-7.7 \%)$ and Serbia $(-3.1 \%)$. There was a 
slight recovery in 2010 and 2011, with another decline in economic activity occurring in 2012. Year 2014 was marked by the catastrophic floods that struck the Balkans, causing a minor GDP growth of $0.3 \%$. Higher GDP growth rates of $2.8 \%$ and 3.5\% were registered in 2015 and 2016. Moreover, a major contribution to GDP growth in 2016 was due to the production and supply of electricity, gas, steam and air conditioning, which accounted for $4.9 \%$ in the overall structure, whereby registering a growth of $19.5 \%$.

On the other hand, a significant contribution to the growth of gross domestic product in 2016 was influenced by the growth of export demand, i.e. exports which amounted to $18.8 \%$, growth of final consumption of $2.3 \%$ and growth of investments in fixed assets amounting to $3.8 \%$.

The following figure displays the movement and trend of GDP growth from 2006 to 2016.

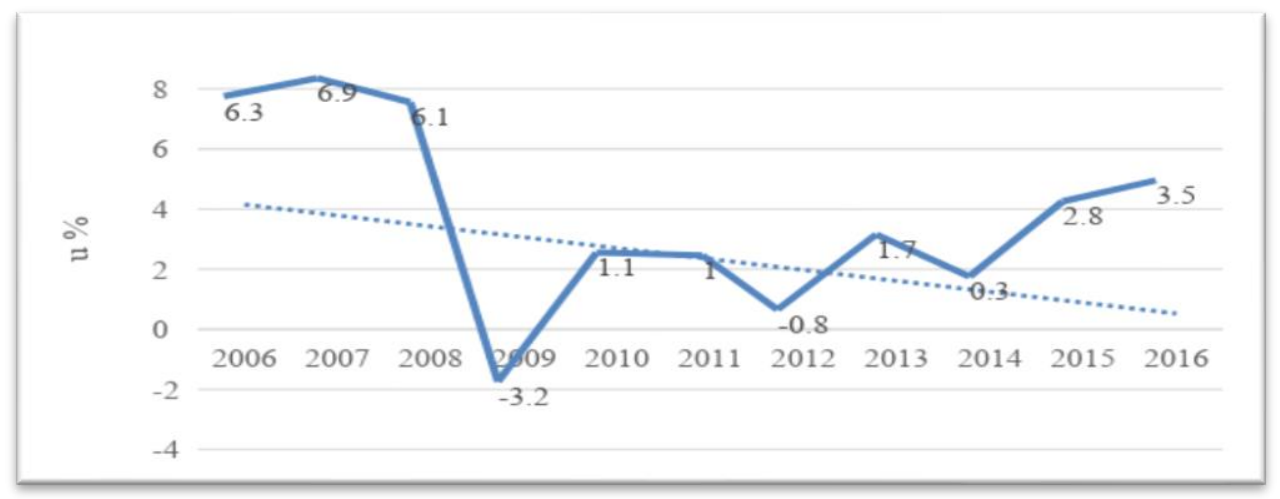

Figure 2. GDP Growth and Trend, 2006-2016.

Source: Institute of Statistics of the Republic of Srpska

Average real GDP growth from the year 2006 to 2016 amounted to $2.3 \%$. Actual values show occasionally significant deviations from the long-term growth trend. The Republic of Srpska mainly follows the movement of economic activities alongside with the EU28 and the countries that are its key foreign trade partners.

\subsection{Final Consumption Variable: Analysis of Final Consumption}

The following figure shows the same trend of final consumption and GDP, which is fairly logical given that the share of final consumption in GDP is on average $95.1 \%$.

Table 1. GDP structure by consumption approach $(\mathrm{GDP}=100)$

\begin{tabular}{|c|c|c|c|c|c|c|c|c|c|c|c|}
\hline & 2007 & 2008 & 2009 & 2010 & 2011 & 2012 & 2013 & 2014 & 2015 & 2016 & $\begin{array}{l}\varnothing \\
2007-20 \\
16\end{array}$ \\
\hline Final consumption & 91,5 & 92,8 & 95,6 & 95,7 & 96,7 & 98,9 & 97,0 & 97,0 & 94,2 & 91,1 & 95,1 \\
\hline \begin{tabular}{l}
\multicolumn{1}{c}{ Final } \\
consumption \\
households
\end{tabular} & 71,6 & 70,7 & 72,0 & 72,6 & 71,9 & 73,3 & 72,2 & 71,6 & 70,2 & 67,8 & 71,4 \\
\hline \begin{tabular}{l}
\multicolumn{1}{c}{ Final } \\
consumption \\
NPISH
\end{tabular} & 0,8 & 1,0 & 0,9 & 1,0 & 0,9 & 1,0 & 0,9 & 1,0 & 0,9 & 0,9 & 0,9 \\
\hline $\begin{array}{l}\text { Final } \\
\text { government } \\
\text { consumption }\end{array}$ & 19,1 & 21,1 & 22,7 & 22,1 & 23,9 & 24,6 & 23,9 & 24,4 & 23,1 & 22,4 & 22,7 \\
\hline $\begin{array}{l}\text { Gross fixed capital } \\
\text { formation }\end{array}$ & 25,2 & 27,9 & 25,3 & 24,2 & 22,7 & 24,9 & 23,5 & 23,7 & 22,5 & 22,5 & 24,2 \\
\hline Inventory changes & $-2,5$ & $-0,8$ & $-3,5$ & $-4,0$ & $-4,5$ & $-6,6$ & $-5,7$ & $-2,8$ & $-0,4$ & 0,2 & $-3,1$ \\
\hline $\begin{array}{l}\text { Export of goods } \\
\text { and services }\end{array}$ & 34,9 & 33,5 & 32,0 & 38,5 & 44,4 & 42,6 & 43,8 & 45,3 & 41,0 & 46,0 & 40,2 \\
\hline $\begin{array}{l}\text { Import of goods } \\
\text { and services }\end{array}$ & 49,1 & 53,4 & 49,4 & 54,4 & 59,3 & 59,8 & 58,6 & 63,2 & 57,3 & 59,8 & 56,4 \\
\hline
\end{tabular}

Source: Institute of statistics of the Republic of Srpska

In the period 2007-2016 the most significant contribution to GDP growth in terms of consumption approach is attributed to the final consumption of $95.1 \%$ of GDP. The average share of final consumption of households and final 
government consumption amounted to $71.4 \%$ and $22.7 \%$. Final consumption largely determined the GDP growth in the year 2012, when it was $98.9 \%$.

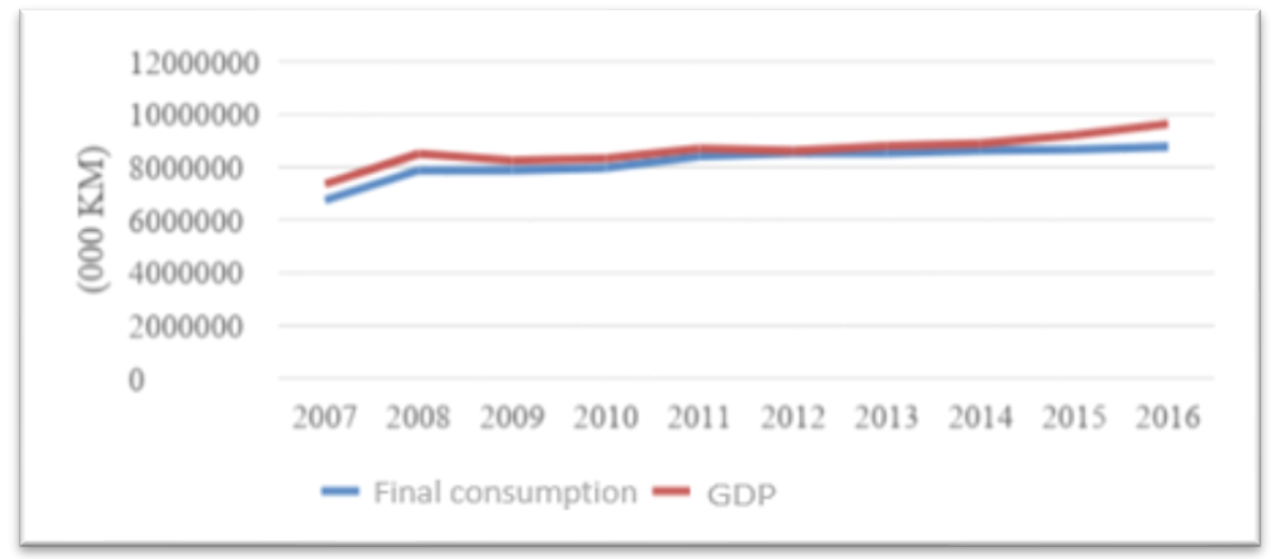

Figure 3. Movement of GDP and final consumption (CF)

Source: Institute of statistics of the Republic of Srpska

The period 2008-2016 saw growth of government consumption, with the exception being the years 2010 and 2015. In the observed period, the government consumption growth rate amounted to $2.3 \%$, whereas the average share in the GDP was $23.1 \%$. The highest growth rate of government consumption was $6.3 \%$ in 2011 , while the biggest drop was $1.9 \%$ which occurred in the year 2015 .

The following figure shows the trends in GDP growth and public spending.

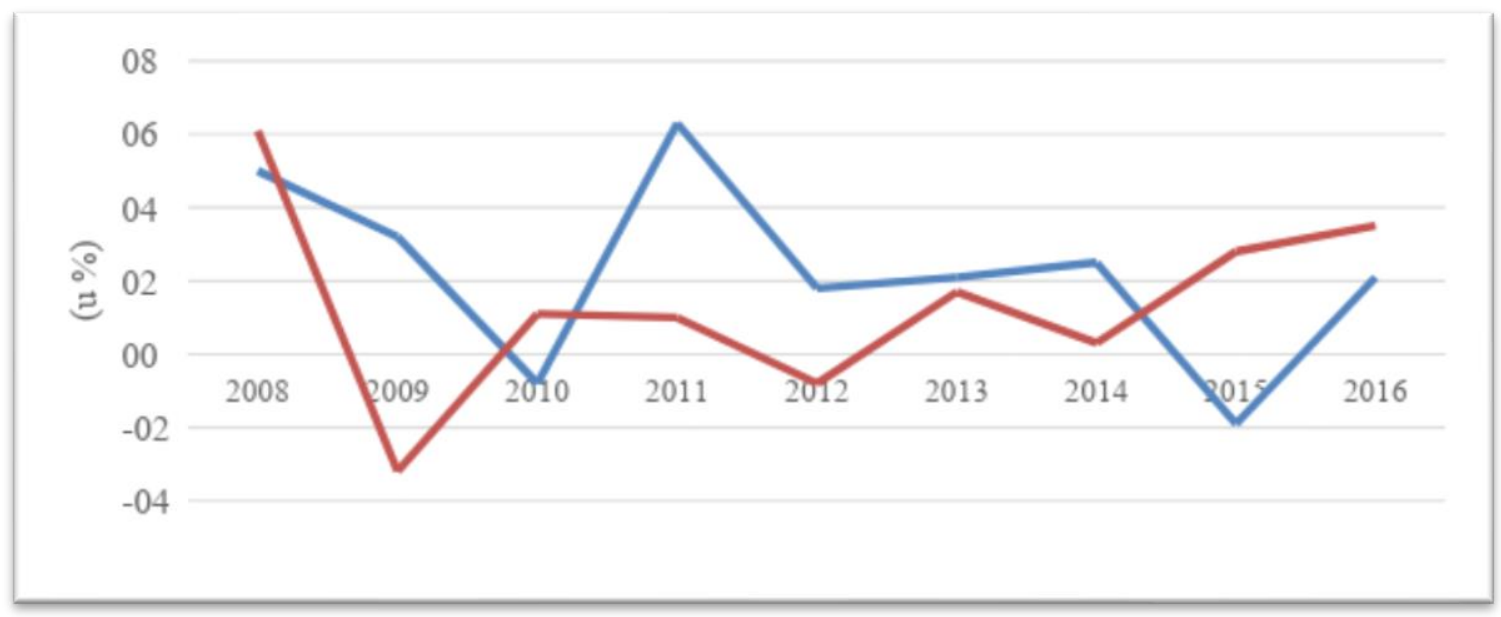

Figure 4. Movement of real GDP and public spending rates

Source: Institute of Statistics of the Republic of Srpska

Consumption by functional classification, i.e. UN-COFOG Classification (Classification of the Functions of the Government) recorded the largest total expenditure in the welfare segment of the RS and the EU28, amounting to $37.5 \%$ and $40.6 \%$ respectively. Likewise, its share in health, education, general public services, etc. is notably significant.

\subsection{Final Consumption Variable: Analysis of Final Consumption}

Prior to the 2008/2009 crisis, the investment rate in the EU was about $20 \%$ of the total GDP. It has been slightly diminished following the crisis (to about 18\%). Smaller and less developed EU member countries do feature slightly higher investment rates than EU's "old" and already developed member countries. The Republic of Srpska and Bosnia and Herzegovina have registered somewhat higher investment rates in comparison to the EU's average.

The following figure shows the movement of GDP and investment. 


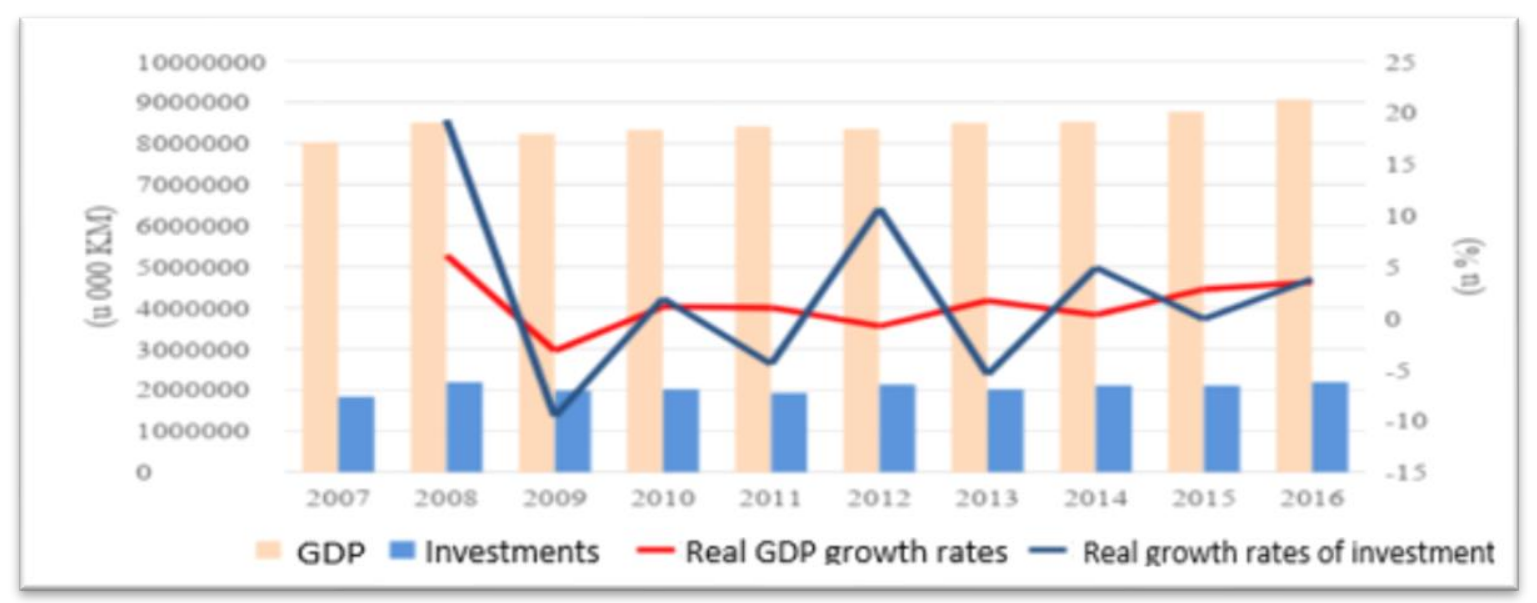

Figure 5. GDP and investments, years 2007-2016

Source: Institute of statistics of the Republic of Srpska, calculation made by the authors

The share of investments in GDP is approximately $24 \%$ on average. The largest share was recorded in 2008, amounting to $27.9 \%$, which is the result of increased economic activity in 2008 .

Real growth rates of investment show high volatility. The largest real growth rate of $19.3 \%$ was recorded in 2008 , to only to register a record drop of $9.6 \%$ in 2009 , which is also the lowest real rate recorded in the observed period. Following the year 2009, the average investment growth rate was $1.6 \%$ with GDP being $1.4 \%$.

\section{Model, Results and Discussion}

Table 2. Gross domestic product (GDP) and final consumption (CF), $2010=100$ (in 000000 BAM)

\begin{tabular}{l|l|l|l|l|l|l|l|l|l|l}
\hline & 2007 & 2008 & 2009 & 2010 & 2011 & 2012 & 2013 & 2014 & 2015 & 2016 \\
\hline GDP & 8.030 & 8.517 & 8.242 & 8.335 & 8.422 & 8.358 & 8.502 & 8.530. & 8.771 & 9.081 \\
\hline CF & 7.558 & 8.011 & 8.003 & 7.979 & 8.035 & 8.011 & 8.059 & 8.212 & 8.335 & 8.527 \\
\hline
\end{tabular}

Source: Institute of statistics of the Republic of Srpska

A regression model is used for the purpose of assessing the impact of independent variables onto GDP growth,.

Table 3. Results of regression analysis between final consumption (CF) and GDP

Dependent Variable: GDP

Method: Least Squares

Date: 11/28/17 Time: 21:51

Sample: 20072016

Included observations: 10

Variable Coefficient Std. Error t-Statistic Prob.

Dependent Variable: GDP

Method: Least Squares

Date: 11/28/17 Time: $21: 51$

Sample: 20072016

Included observations: 10

\begin{tabular}{lrlrr}
\hline \multicolumn{1}{c}{ Variable } & Coefficient & \multicolumn{1}{c}{ Std. Error } & t-Statistic & \multicolumn{1}{c}{ Prob. } \\
\hline \multicolumn{1}{c}{ CF } & -182642.3 & 1040168. & -0.175589 & 0.8650 \\
\hline R-squared & 1.072908 & \multicolumn{1}{c}{0.128780} & 8.331335 & 0.0000 \\
Adjusted R-squared & 0.896656 & Mean dependent var & 8479473. \\
S.E. of regression & 0.883738 & S.D. dependent var & 288333.8 \\
Sum squared resid & 98313.94 & Akaike info criterion & 26.00658 \\
Log likelihood & $7.73 E+10$ & Schwarz criterion & 26.06709 \\
F-statistic & -128.0329 & Hannan-Quinn criter. & 25.94019 \\
Prob (F-statistic) & 69.41114 & Durbin-Watson stat & 1.767425 \\
\hline
\end{tabular}


Source: Data analysis made by the authors.

The regression equation can be written in the form of GDP $=-182.642 .300+1,072908 \mathrm{CF}$. Thus, the increase in final consumption by $1 \%$ leads to GDP growth in the same percentage, that is, by $1.072908 \%$. The probability value $(\mathrm{p}=$ $0,000)$ is less than 0.05 , meaning that the zero hypothesis $(\mathrm{H} 0)$ is rejected and it is concluded that final consumption is a statistically significant variable for analysing GDP.

With certainty, we can reject $\mathrm{H}_{0}$, because the coefficient that is estimated is different from zero and the value of $\mathrm{t}$-statistics is higher than the value from the table.

There is a linear relationship between the variation of the observed occurrences in the basic set, i.e. CF affects GDP, which means that the given regression line can be used for making estimates.

The determination coefficient $\left(\mathrm{R}^{2}\right)$ shows how much variable $\mathrm{X}$ explains variations of $\mathrm{Y}$. Since $\mathrm{R}^{2}$ is $90 \%$, it means that the GDP variations are $90 \%$ determined by the final consumption variations and that $10 \%$ of the variations are determined by other factors, meaning that we have a minimum risk model for economic analyses. The determination coefficient $\mathrm{R}^{2}=0.896656$ gravitates towards the unit value and shows that the estimated regression model approximates observation data very well and with high reliability. This is also confirmed by the adjusted determination coefficient $\mathrm{R}^{2}$, which is 0.883738 .

Durbin-Watson (D.W.) statistics is 1.767425 , which implies that there is a positive serial correlation between the residuals, which is common in time series of data.

\subsection{Analysis of the Impact of Final Consumption onto GDP}

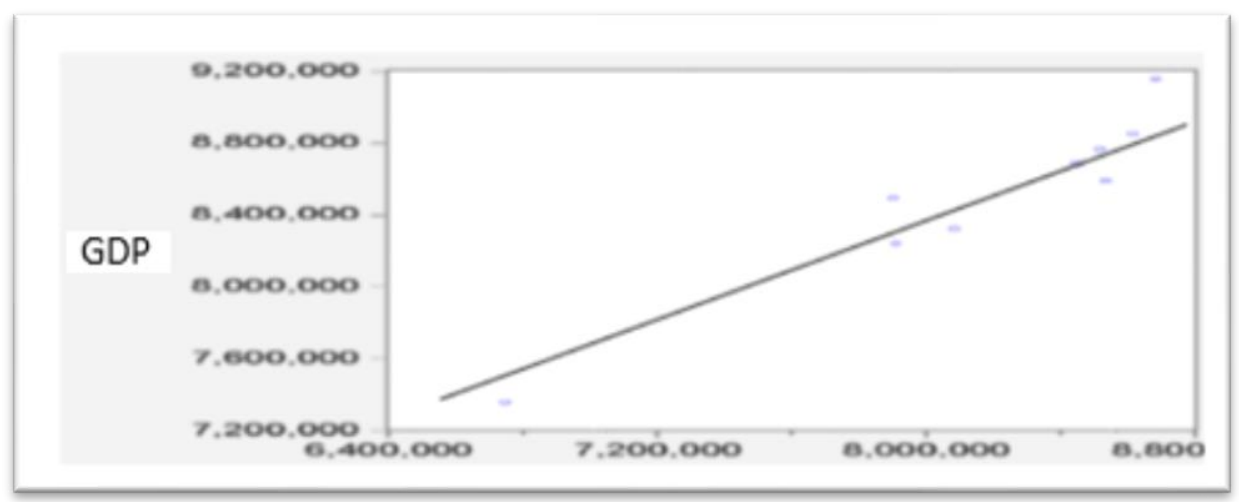

Figure 6. Scatter plot of GDP and CF

Source: Data analysis performed by the authors

Scatter plot shows a direct positive linear relationship between GDP and final consumption. Final consumption growth influences GDP growth, indicating a correlation coefficient of 0.946919.

Table 4. Correlation analysis between GDP and CF

\begin{tabular}{l|l|l}
\hline & GDP & CF \\
\hline GDP & 1.000000 & 0.946919 \\
\hline CF & 0.946919 & 1.000000 \\
\hline
\end{tabular}

Source: Data analysis performed by the authors

Descriptive GDP statistics:

Series: GDP

Sample 20072016

Observation 10

Mean

Median

Maximum

Minimum 


$\begin{array}{lr}\text { Std. Dev. } & 28833 \\ \text { Skewness } & 0.660 \\ \text { Kurtosis } & 3.268 \\ & \\ \text { Jarque-Bera } & 0.756 \\ \text { Probabolity } & 0.685\end{array}$

The figure above contains test stats which provide a more detailed analysis of GDP based on EViews. In the observed period from 2007 to 2016, the average value of GDP amounted to 8,479,473,000 BAM, with a minimum value of 8,030,997,000 BAM, whereas the maximum value was 9.081.537.000 BAM. Gross domestic product has a growth trend, as the minimum value was recorded back in 2007 and the maximum value in the year 2016. The median (central value) of the observed series is $8,462,434,000 \mathrm{BAM}$.

The GDP movement in the observed interval is moderately distorted, i.e. the data are not perfectly symmetrical, as the skewness amounts to 0.660 , whereas the value of kurtosis, representing the flattening value is greater than 3 , meaning that the distribution is leptokurtic (with a pointier and narrower peak compared to normal distribution when kurtosis has a value of 3).

Descriptive CF statistics

Series: $\mathrm{CF}$

Sample 20072016

Observation 10

Mean

80734

Median

80235

Maximum

85274

Minimum

Std. Dev.

Skewness

$-0.172$

Kurtosis

Jarque-Bera

0.146

Probabolity

The average value of final consumption in the observed period was 8.073.490.000 BAM, while the minimum and maximum value were registered in 2007 and in 2016, respectively, as was the case for GDP. Final consumption has a growth trend, similar to GDP. However, in the year 2008, prior to the onset of the economic crisis, the growth rate was $6 \%$, while in the period 2008-2016. average annual growth rate was $1.4 \%$. The movement of the CF in the given period is symmetrical because the skewness value is $-0,173$, while kurtosis is greater than 3 , meaning that the distribution is leptokurtic. As we already know, final consumption includes household consumption, government consumption and non-profit institutions serving households (NPISH), with the average share in the GDP structure being 71.4\%, 22.7\% and $0.9 \%$, respectively, while the average share of final consumption in the GDP structure is $95.1 \%$.

\subsection{Analysis of the Impact of Investments onto GDP}

The results of the assessment show that the total effects of foreign direct investment are positively related to growth. Whereas labour, openness of trade and economic freedom are the key determinants of foreign direct investment, which in return encourages further growth (Iamsiraroj, 2016).

Table 5. GDP and gross fixed capital formation, $2010=100$ (in 000 BAM)

\begin{tabular}{l|l|l|l|l|l|l|l|l|l|l}
\hline & 2007 & 2008 & 2009 & 2010 & 2011 & 2012 & 2013 & 2014 & 2015 & 2016 \\
\hline GDP & 8.030 .997 & 8.517 .316 & 8.242 .848 & 8.335 .987 & 8.422 .489 & 8.358 .441 & 8.502 .378 & 8.530 .769 & 8.771 .966 & 9.081 .537 \\
\hline I & 1.835 .292 & 2.189 .503 & 1.979 .311 & 2.016 .918 & 1.926 .157 & 2.132 .256 & 2.014 .982 & 2.113 .716 & 2.111 .602 & 2.191 .843 \\
\hline
\end{tabular}

Source: Institute of Statistics of the Republic of Srpska 
Table 6. Results of regression analysis with respect to investments into fixed capital formation and GDP

Dependent Variable: GDP

Method: Least Squares

Date: 11/28/17 Time: 22:05

Sample: 20072016

Included observations: 10

\begin{tabular}{lrllr}
\hline \multicolumn{1}{c}{ Variable } & Coefficient & Std. Error & t-Statistic & \multicolumn{1}{c}{ Prob. } \\
\hline \multicolumn{1}{c}{ C } & 4708420. & 1194668. & 3.941196 & 0.0043 \\
\multicolumn{1}{c}{1.838499} & 0.581587 & 3.161179 & 0.0134 \\
\hline R-squared & 0.555384 & Mean dependent var & 8479473. \\
Adjusted R-squared & 0.499807 & S.D. dependent var & 288333.8 \\
S.E. of regression & 203922.2 & Akaike info criterion & 27.46572 \\
Sum squared resid & $3.33 E+11$ & Schwarz criterion & 27.52624 \\
Log likelihood & -135.3286 & Hannan-Quinn criter. & 27.39933 \\
F-statistic & 9.993053 & Durbin-Watson stat & 1.622491 \\
Prob(F-statistic) & 0.013371 & & \\
\hline
\end{tabular}

Source: Data analysis performed by the authors

The regression equation with reference to investments and GDP is: GDP $=4.708 .420 .000+1.84 \mathrm{I}$.

Gross fixed capital formation has a multiplicative impact on GDP, where an increase in investment by $1 \%$ leads to an increase in GDP by an average of 1.84. The coefficient of determination is $55.5 \%$, which shows that the GDP variation is determined by the variation of investments with $55.5 \%$. The value of Durbin-Watson is 1.622491 , which shows a positive serial correlation between the residuals. The average share of investments in GDP is $24.2 \%$.

Descriptive statistics of investments:

Series: I

Sample 20072016

Observation 10

Mean

Median 20642

Maximum

Minimum

Std. Dev.

Skewness

$-0.443$

Kurtosis

2.166

Jarque-Bera

0.616

Probability

0.734

The value of investments in fixed assets within the observed interval is symmetrical given the skewness value, whereas kurtosis is $<3$, meaning that the distribution of the series is flatter or platykurtic.

Table 7. Correlation analysis of GDP and I

\begin{tabular}{l|l|l}
\hline & GDP & I \\
\hline GDP & 1.000000 & 0.745241 \\
\hline I & 0.745241 & 1.000000 \\
\hline
\end{tabular}

Source: Data analysis performed by the authors

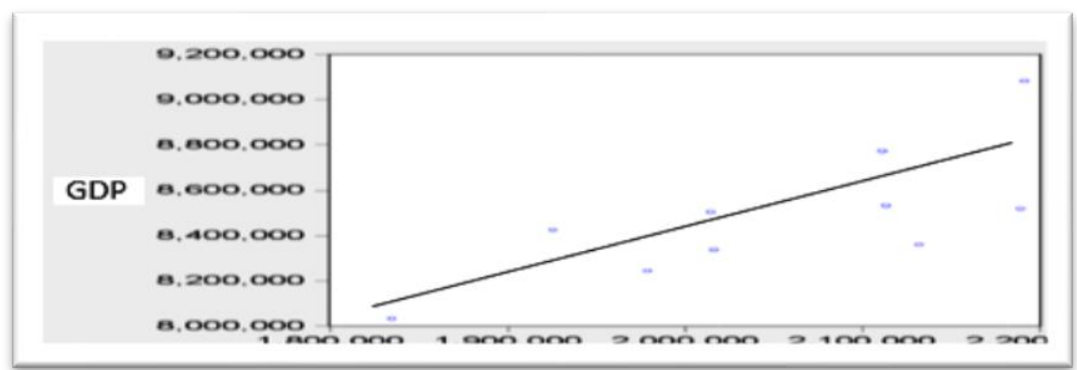

Figure 7. Scatter plot of GDP $\mathrm{i}$ investments in fixed assets (in 000 BAM) 
Source: Data analysis performed by the authors

The scatter plot above displays a direct linear relationship between GDP and investments in fixed assets.

\section{Conclusion}

According to most standards, the Republic of Srpska and Bosnia and Herzegovina are classified as small economies. They are in the final phase of transition and in the process of accession into the European Union. Economic problems are a consequence of the inherited economic structure, as well as of the impossibility of "directing" the society towards faster development, reform and restructuring in line with the new standards imposed by the global economy.

The survey confirmed that from 2006 to 2016, the real economic growth rates in the Republic of Srpska and Bosnia and Herzegovina are approximately equal. The average GDP growth in the period 2006-2016 amounts to 2.3\%. The GDP value occasionally deviates from the long-term growth trend. This is explained by the impact of the crisis (2008/2009) and other internal and external disturbances and problems (floods, etc.) which the small economies are more susceptible to. Due to the fact that its largest trade partners and investors are from the European Union, the Republic of Srpska follows the trends of EU 28 member states. As a direct consequence of the crisis, the GDP decline in 2009 and 2012 was also recorded in the Republic of Srpska, the EU, Croatia, Italy, Slovenia, Serbia and other countries. Furthermore, the largest contribution to GDP growth in the same period was due to final consumption (95.1\% of GDP).

The average share of household consumption and government consumption is $71.4 \%$ and $22.7 \%$ respectively, thereby causing the final consumption to predominantly determine the GDP trend (for example, in 2012 it amounted to 98.9\%). Government consumption recorded growth (with exception being the years 2010 and 2015). In the given period, government consumption growth was $2.3 \%$ whereas the average share in GDP amounted to $23.1 \%$. Its highest increase was recorded in 2011, 6.3\%, with the greatest decline being registered in 2015, amounting to $1.9 \%$.

Investments account for about $24.2 \%$ of GDP. Such high rate is above the EU average. The highest share recorded in 2008 amounted to $27.9 \%$, being the result of a larger inflow of investments and economic activities in 2007 and 2008.

Real growth in investment shows high volatility. The highest growth of $19.3 \%$ occurred in 2008 , only to be followed with a drop amounting to $9.6 \%$ in 2009, with the lowest real growth rate in the observed period. Following the year 2009 the average investment growth was $1.6 \%$, while GDP grew at a rate of $1.4 \%$.

Statistical analysis has mostly confirmed the subject hypotheses.

- The equation of GDP regression $=-182.642 .300+1,072908 \mathrm{CF}$ shows that final consumption growth of $1 \%$ leads to a GDP growth of $1.1 \%$. The zero hypothesis $\left(\mathrm{H}_{0}\right)$ has been rejected since the final consumption is a statistically significant variable for analysing GDP.

- The equation of GDP regression $=4.708 .420 .000+1,84 \mathrm{I}$ shows that investments have a multiplicative impact onto GDP. Investment growth of $1 \%$ leads to a GDP growth of 1.84 . The determination coefficient is $55.5 \%$, consequently meaning that GDP variations are determined by investment variations with $55.5 \%$.

- Scatter plot shows a direct positive linear relationship between GDP and final consumption. Growth in consumption leads to GDP growth, since the correlation coefficient equals to 0.946919. Scatter plot also shows a direct linear relationship between GDP and investment.

Likewise, Durbin-Watson (D.W.) statistics demonstrates the correlation between the independent variables and the dependent variable. D.W. for final consumption equals to 1.767425 , that is, the correlation between the residuals is positive. D.W. value for investments is 1.622491 , that is, the correlation between the residuals is positive.

The general conclusion is that the final consumption and investments affect the growth rates of GDP in small transition economies such as the Republic of Srpska. However, such development orientation is accompanied by certain issues. The first one being a high share of government (public) consumption in total consumption, the consequence of which is the growth of public debt. Another problem is the inefficiency of the investments invested, because despite the high average investment rate of over $24 \%$ for the observed period, there are no adequate responses in the faster GDP growth. Obviously, reforms in the Republic of Srpska and Bosnia and Herzegovina need to be completed, accompanied by the liberalization of the economy, speeding up of the European integration, industry restructuring and relying on exports. The results of the analysis show that it is necessary to reduce the high costs of public institutions and to increase the productivity and competitiveness of the economy.

\section{References}

Alimi, N. (2016). Volatility and growth in developing countries: An asymmetric effect. The Journal of Economic Asymmetries, 14, 179-188. https://doi.org/10.1016/j.jeca.2016.08.001 
Alonso, J. M., Clifton, J., \& Díaz-Fuentes, D. (2017). The impact of government outsourcing on public spending: Evidence from European Union countries. Journal of Policy Modeling, 39(2), 333-348. https://doi.org/10.1016/j.jpolmod.2017.01.007

Borgonovo, E., \& Peccati, L. (2006). The importance of assumptions in investment evaluation. International Journal of Production Economics, 101(2), 298-311. https://doi.org/10.1016/j.ijpe.2005.01.009

Chatterjee, S., Gibson, J., \& Rioja, F. (2017). Optimal public debt redux. Journal of Economic Dynamics and Control, 83, 162-174.https://doi.org/10.1016/j.jedc.2017.08.005

Ha, J., \& Feng, M. (2018). Conditional Conservatism and Labor Investment Efficiency. Journal of Contemporary Accounting \& Economics. https://doi.org/10.1016/j.jcae.2018.05.002

Iamsiraroj, S. (2016). The foreign direct investment-economic growth nexus. International Review of Economics \& Finance, 42, 116-133. https://doi.org/10.1016/j.iref.2015.10.044

Juknys, R., Liobikienè, G., \& Dagiliūtè, R. (2018). Deceleration of economic growth-The main course seeking sustainability in developed countries. Journal of Cleaner Production, 192, 1-8. https://doi.org/10.1016/j.jclepro.2018.04.231

Kaminarides, J., \& Nissan, E. (1993). The effects of international debt on the economic development of small countries. World Development, 21(2), 227-232. https://doi.org/10.1016/0305-750X(93)90018-5

Krugman \& Obstfeld, Međunarodna ekonomija - teorija i politika (prevod sa engl.), DATASTATUS, Beograd, str. 232.

Kui, W. L. (2017). Chapter 5 Capitalism and Socialism Sustainability Versus Popularity, Redefining Capitalism in Global Economic Development, Pages 59-73. https://doi.org/10.1016/B978-0-12-804181-9.00005-7

Kuznets, S. (1960). Economc growth of small nations, International Economic Association Conference Volumes, 14-32, pp. 14.

Makiela, K., \& Ouattara, B. (2018). Foreign direct investment and economic growth: Exploring the transmission channels. Economic Modelling, 72, 296-305. https://doi.org/10.1016/j.econmod.2018.02.007

Morozumi, A., \& Veiga, F. J. (2016). Public spending and growth: The role of government accountability. European Economic Review, 89, 148-171. https://doi.org/10.1016/j.euroecorev.2016.07.001

Sayari, N., Sari, R., \& Hammoudeh, S. (2018). The impact of value added components of GDP and FDI on economic freedom in Europe. Economic Systems. https://doi.org/10.1016/j.ecosys.2017.03.003

Shen, W., Yang, S. C. S., \& Zanna, L. F. (2018). Government spending effects in low-income countries. Journal of Development Economics. https://doi.org/10.1016/j.jdeveco.2018.02.005

Statistical Yearbook of the Federation of $\mathrm{BiH}$ 2017. Federal Statistics Office of Federation of $\mathrm{BiH}$. https://docs.google.com/viewerng/viewer?url=http://fzs.ba/wp-content/uploads/2017/12/Godisnjak-2017.pdf

Statistical Yearbook of the Republic of Srpska 2017, Republic of Srpska, Institute of Statistics of RS, BIH. http://www2.rzs.rs.ba/static/uploads/bilteni/godisnjak/2017/StatistickiGodisnjak_2017_WEB.pdf

Ventelou, B., \& Bry, X. (2006). The role of public spending in economic growth: Envelopment methods. Journal of Policy modeling, 28(4), 403-413. https://doi.org/10.1016/j.jpolmod.2005.10.008

Williams, M. A., Baek, G., Li, Y., Park, L. Y., \& Zhao, W. (2017). Global evidence on the distribution of GDP growth rates. Physica A: Statistical Mechanics and its Applications, 468, 750-758. https://doi.org/10.1016/j.physa.2016.11.124

\section{Copyrights}

Copyright for this article is retained by the author(s), with first publication rights granted to the journal.

This is an open-access article distributed under the terms and conditions of the Creative Commons Attribution license which permits unrestricted use, distribution, and reproduction in any medium, provided the original work is properly cited. 